\title{
Sensor Ultrasonic dan Servo Motor untuk Selection Belt Conveyor Prototype Berbasis Arduino
}

\author{
Adhie Tri Wahyudi" ${ }^{*}$, Bagus Ismail Adhi Wicaksana ${ }^{2}$ \\ ${ }_{1,2}$ Program Studi S1 Teknik Industri, Universitas Setia Budi, \\ Jalan Letjend Sutoyo, Mojosongo, Jebres, Surakarta, 57127 \\ e-mail: ${ }^{* 1}$ adhie.wahyudi@gmail.com, ${ }^{2}$ bagoeswitjaksana@gmail.com
}

\begin{abstract}
Abstrak
Penelitian ini bertujuan untuk melakukan rancang bangun prototype of selection belt conveyor. Requirement specification yang menjadi dasar perancangan adalah sebuah conveyor yang dilengkapi dengan perangkat pendeteksi tinggi benda dan penyeleksi berdasarkan tinggi objek. Penelitian ini dilakukan dengan tahapan desain sketsa menggunakan software SketchUp, perencanaan skema pengkabelan dengan bantuan software Fritzing, perancangan kode program mikrokontroler Arduino, perakitan belt conveyor dan ujicoba fungsional. Hasil ujicoba yang dilakukan dengan tiga kali repetisi memperlihatkan bahwa prototipe mampu melakukan fungsi operasional sebagaimana requirement specification yang diharapkan. Prototipe mampu mendeteksi objek benda yang bergerak melewati sensor ultrasonic, kemudian tangan motor servo mampu melakukan seleksi terhadap objek yang tingginya bersesuaian. Tiga box keranjang output berisi tiga objek hasil seleksi yang sama tingginya.
\end{abstract}

Kata kunci: prototipe conveyor belt, selection belt conveyor, arduino, sensor ultrasonic, motor servo, motor stepper

\begin{abstract}
This research aims to design a prototype of selection belt conveyor. Requirement specification which is the basis of design is a conveyor equipped with an object height detection device and a selection based on object height. This research was carried out with the sketch design stages using SketchUp software, planning the wiring scheme with the help of the Fritzing software, designing the Arduino microcontroller program code, assembling the conveyor belt and functional testing. The results of trials conducted with three repetitions showed that the prototype could perform its operational function as expected in the specifications. The prototype is able to detect objects moving through the ultrasonic sensor, then the servo motor's hand is able to make selections of objects whose height corresponds. Three output basket boxes contain three objects of the same selection.
\end{abstract}

Keywords: belt conveyor prototype, selection belt conveyor, arduino, ultrasonic sensor, servo motor, stepper motor

\section{PENDAHULUAN}

Dewasa ini industri kelas menengah ke atas di Indonesia banyak yang sudah menerapkan controlling system pada operasionalnya. Upaya penerapan teknologi tinggi ini adalah cara untuk meningkatkan efektivitas, efisiensi dan nilai dari produk yang dihasilkannya (Mulyono et al., 2017). Belt Conveyor (konveyor sabuk) adalah peralatan pemindah muatan yang banyak digunakan oleh industri. Belt Conveyor, atau dapat juga disebut ban berjalan, digunakan untuk memindahkan muatan satuan (unit load) maupun muatan curah (bulk load) sepanjang garis lurus 
(horizontal) atau sudut inklinasi terbatas (Nugraha, 2016). Konveyor sabuk memiliki komponen utama berupa sabuk yang berada di atas sekumpulan roller penumpu. Belt Conveyor menggunakan tenaga penggerak berupa motor listrik dengan perantara roda gigi yang dikopel ke pulley penggerak. Material diletakkan diatas sabuk dan bersama sabuk bergerak kesatu arah.

Tahap awal penelitian, ditemukan bahwa sebagian besar industri berbasis teknologi tinggi menggunakan controlled belt conveyor untuk memindahkan barang dari satu titik ke titik lain. Biasanya, sebuah mikrokontroler ataupun programmable logic control (PLC) digunakan sebagai alat kontrol pada belt conveyor yang beroperasi. Penggunaan belt conveyor dengan mikrokontroler merupakan bagian dari upaya penerapan teknologi otomatisasi pada sebuah indutri. Tabel 1 memperlihatkan sebagian hasil identifikasi dan pengamatan penggunaan belt conveyor pada industri di wilayah DIY dan Jawa Tengah.

Dari Tabel 1 dapat dilihat bahwa sebaran industri pengguna belt conveyor. Adi Sumarmo Airport, Adi Sutjipto Airport dan PT. Coca Cola Amatil Indonesia dapat dikategorikan sebagai industri skala besar. Ketiga industri besar tersebut menggunakan banyak jenis belt conveyor pada aktivitasnya. Sebaliknya, pengepul pasir di daerah Pandansimping, Klaten dan Fitness Center di area Stadion Manahan, Solo menjadi representasi industri skala menengah. Industri ini juga menggunakan belt conveyor pada untuk mendukung aktivitas sehari-harinya.

Tabel 1. Indentifikasi penggunaan belt conveyor di industri

\begin{tabular}{|c|c|c|c|}
\hline No & Industri & $\begin{array}{l}\text { Jenis Konveyor } \\
\text { Sabuk }\end{array}$ & Penggunaan \\
\hline 1 & $\begin{array}{l}\text { Adi Sumarmo } \\
\text { Airport }\end{array}$ & $\begin{array}{l}\text { Belt conveyor } \\
\text { (endless belt) }\end{array}$ & $\begin{array}{l}\text { Mengirim tas penumpang dari meja } \\
\text { check in ke dalam ruang penumpukan } \\
\text { bagasi sebelum naik ke dalam } \\
\text { pesawat }\end{array}$ \\
\hline 2 & $\begin{array}{l}\text { Adi Sumarmo } \\
\text { Airport }\end{array}$ & $\begin{array}{l}\text { Belt conveyor } \\
\text { (potongan-potongan } \\
\text { belt) }\end{array}$ & Belt conveyor pengambilan bagasi \\
\hline 3 & $\begin{array}{l}\text { Adi Sumarmo } \\
\text { Airport }\end{array}$ & $\begin{array}{l}\text { Belt conveyor } \\
\text { (endless belt) }\end{array}$ & $\begin{array}{l}\text { Bagasi handling: Memindahkan } \\
\text { koper dan bagasi lainnya dari tow } \\
\text { truck \& baggage trailer ke pesawat }\end{array}$ \\
\hline 4 & $\begin{array}{l}\text { Adi Sumarmo } \\
\text { Airport }\end{array}$ & $\begin{array}{l}\text { Belt conveyor } \\
\text { (endless belt) }\end{array}$ & 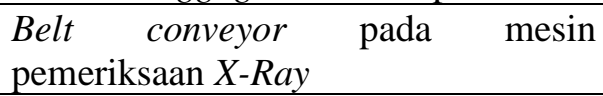 \\
\hline 5 & $\begin{array}{l}\text { Pengepul pasir } \\
\text { (Pandan Simping, } \\
\text { Klaten) }\end{array}$ & $\begin{array}{l}\text { Bucket belt conveyor } \\
\text { (konveyor dengan } \\
\text { bentuk cekung } \\
\text { dengan permukaan } \\
\text { belt sersan) }\end{array}$ & $\begin{array}{l}\text { Menaikkan pasir/ kerikil ke mesin } \\
\text { pemecah kerikil }\end{array}$ \\
\hline 6 & $\begin{array}{l}\text { Coca Cola Amatil } \\
\text { Indonesia }\end{array}$ & $\begin{array}{l}\text { PVC conveyor } \\
\text { (dengan custom } \\
\text { dinding untuk botol) }\end{array}$ & $\begin{array}{l}\text { Pengisian air dan pemasangan tutup } \\
\text { botol }\end{array}$ \\
\hline 7 & $\begin{array}{l}\text { Adi Sumarmo } \\
\text { Airport, Mall }\end{array}$ & $\begin{array}{l}\text { Conveyor slab } \\
\text { variabel (belt pada } \\
\text { eskalator) }\end{array}$ & Eskalator (Tangga berjalan) \\
\hline 8 & $\begin{array}{l}\text { Adi Sutjipto Airport, } \\
\text { Mall }\end{array}$ & $\begin{array}{l}\text { Nylon belt conveyor } \\
\text { (endless belt) }\end{array}$ & Travelator (Trotoar berjalan) \\
\hline 9 & Fitness Center/ Gym & $\begin{array}{l}\text { Belt conveyor } \\
\text { (endless belt) }\end{array}$ & Treadmill \\
\hline
\end{tabular}


Pada tabel 1 di atas, kita juga dapat melihat bahwa terdapat berbagai jenis dan karakter belt conveyor yang digunakan oleh industri. Sebagai contoh, terdapat perbedaan karakter antara belt conveyor di bagian pengambilan bagasi dengan belt conveyor di mesin pemeriksaan $x$-ray. Kedua belt conveyor ini berbeda bahan pada bagian belt/ sabuk. Sabuk pada conveyor pengambilan bagasi di bandara Adi Sumarmo berbentuk potongan-potongan sabuk. Hal ini karena disesuaikan dengan lintasan conveyor yang berbentuk oval. Sementara jenis sabuk pada conveyor mesin $x$-ray adalah jenis endless belt (lihat Gambar 1). Sementara itu, walaupun sama-sama menggunakan sabuk berjenis endless belt, conveyor pada mesin $x$-ray (Gambar 1kanan) maupun travelator (Gambar 2) juga memiliki perbedaan karakter teknologi.
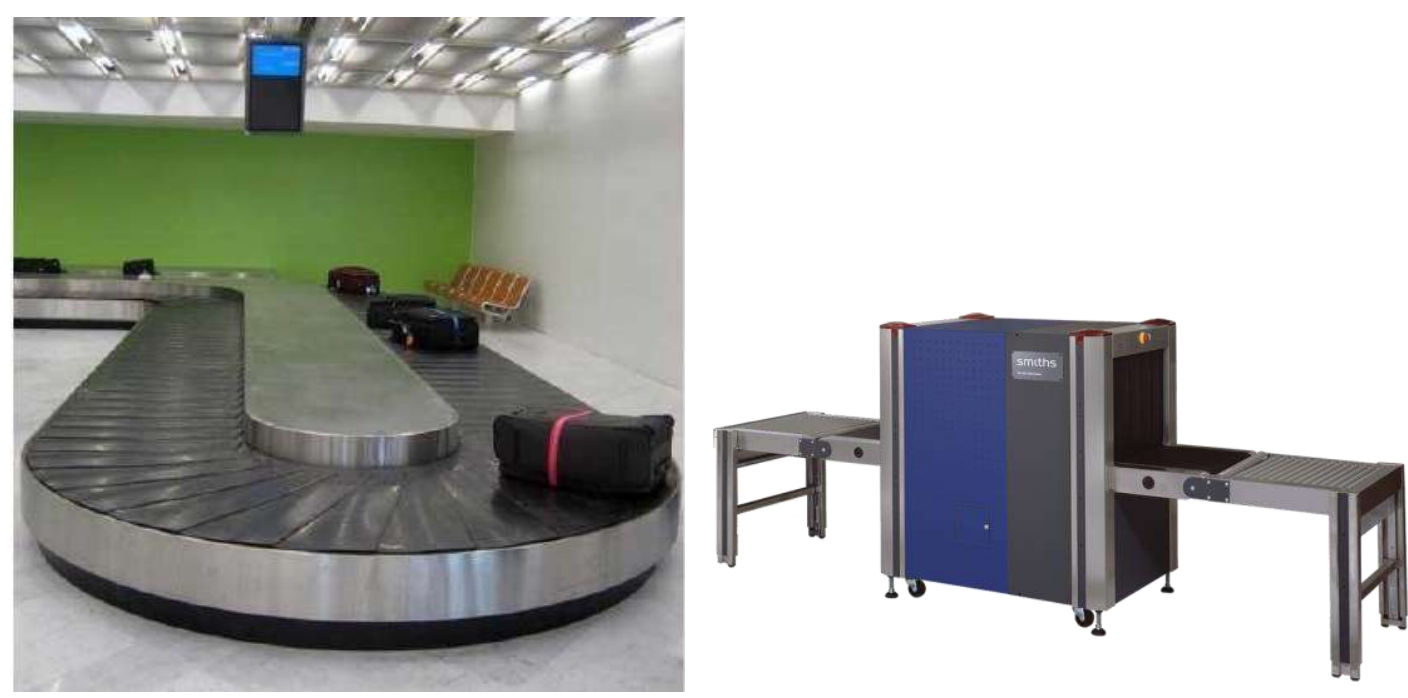

Gambar 1. Perbedaan sabuk pada conveyor pengambilan bagasi dan conveyor $x$-ray

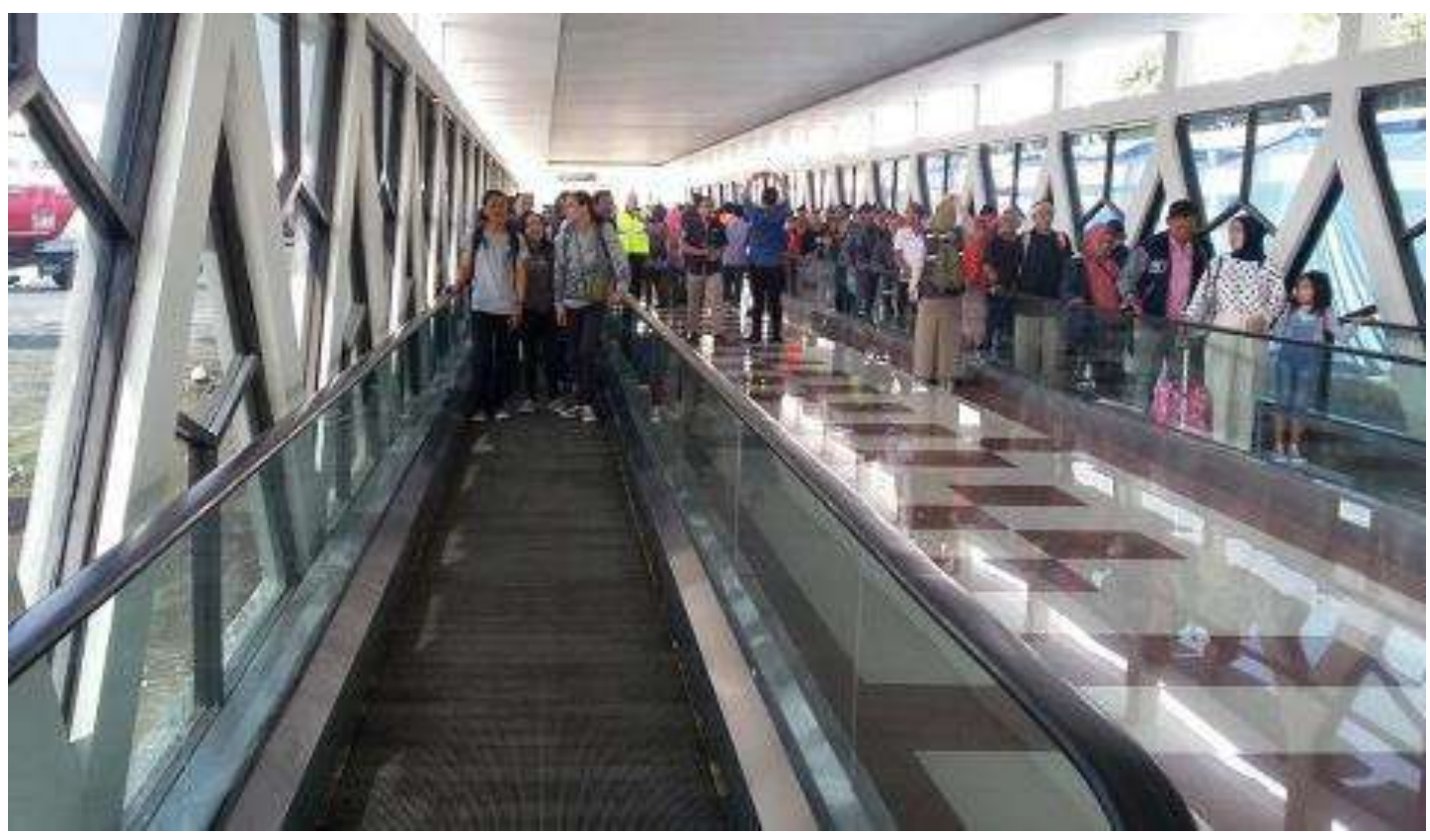

Gambar 2. Travelator (implementasi belt conveyor) di Adi Sutjipto Airport

Dari penjelasan penggunaan belt conveyor pada berbagai industri di atas, 
terlihat bahwa kebutuhan akan adanya conveyor yang dapat membantu pekerjaan manusia sangatlah dibutuhkan. Bahkan penggunaannya bukan saja terfokus pada pendistribusian barang, melainkan juga perpindahan barang dan manusia.

Jika diperhatikan, ketika industri akan mengimplementasikan teknologi belt conveyor maka mereka bukan membeli mesin conveyor kemudian langsung menggunakannya. Mengimplementasikan belt conveyor berarti membeli custom (Mulyono et al., 2017). Hal ini dikarenakan harus menyesuaikan dengan kebutuhan yang spesifik. Perbedaan tata letak pabrik dapat menyebabkan kebutuhan belt conveyor yang berbeda pula.

Dalam implementasinya, belt conveyor sering mengalami permasalahan seperti berkurangnya kapasitas angkut atau kecepatan belt yang tidak sesuai dengan kebutuhan (Nurhabiby, 2013). Oleh karena itu, penelitian ini bertujuan melakukan rancang bangun prototipe belt conveyor yang dikontrol oleh sistem kendali mikrokontroler. Prototipe belt conveyor ini dirancang menyesuaikan kebutuhan laboratorium manufaktur program studi Teknik Industri di Universitas Setia Budi. Prototipe yang dirancang bangun nantinya menjadi dasar desain belt conveyor skala 1:1. Adapun requirement specification yang menjadi dasar perancangan adalah sebuah conveyor yang dilengkapi dengan perangkat pendeteksi tinggi benda. Jika tinggi benda melebihi $6 \mathrm{~cm}$ maka barang akan dipindah ke keranjang 1, sementara jika tinggi benda antara $3 \mathrm{sd} 6 \mathrm{~cm}$ maka dipindah ke keranjang 2. Sedangkan jika tinggi benda kurang dari $3 \mathrm{~cm}$ maka benda dibiarkan terus berjalan pada hingga ujung conveyor.

\section{METODE PENELITIAN}

Tahapan penelitian yang dilakukan seperti yang ditampilkan pada Gambar 3 . Penelitian diawali dengan tahap desain. Proses desain dilakukan dengan bantuan software SketchUp. SketchUp adalah aplikasi 3D modeling yang powerfull (Bhirawa, 2018). Desain dengan software SketchUp dilakukan dengan tujuan memperoleh gambar rancangan belt conveyor yang akan dibangun.

Setelah diperoleh gambar desain, maka akan diperoleh gambaran bill of material beserta biaya yang dibutuhkan untuk membangun belt conveyor system. Berdasarkan gambar desain pula, dapat dilakukan perencanaan skema pengkabelan. Perancangan skema pengkabelan dilakukan dengan bantuan software Fritzing. Penelitian kemudian dilanjutkan proses perakitan belt conveyor dan perancangan kode program mikrokontroler.

Setelah belt conveyor selesai dibangun, langkah berikutnya adalah ujicoba sistem. Penelitian ini selesai ketika belt conveyor berjalan dan berfungsi sesuai dengan requirement yang dikehendaki. 


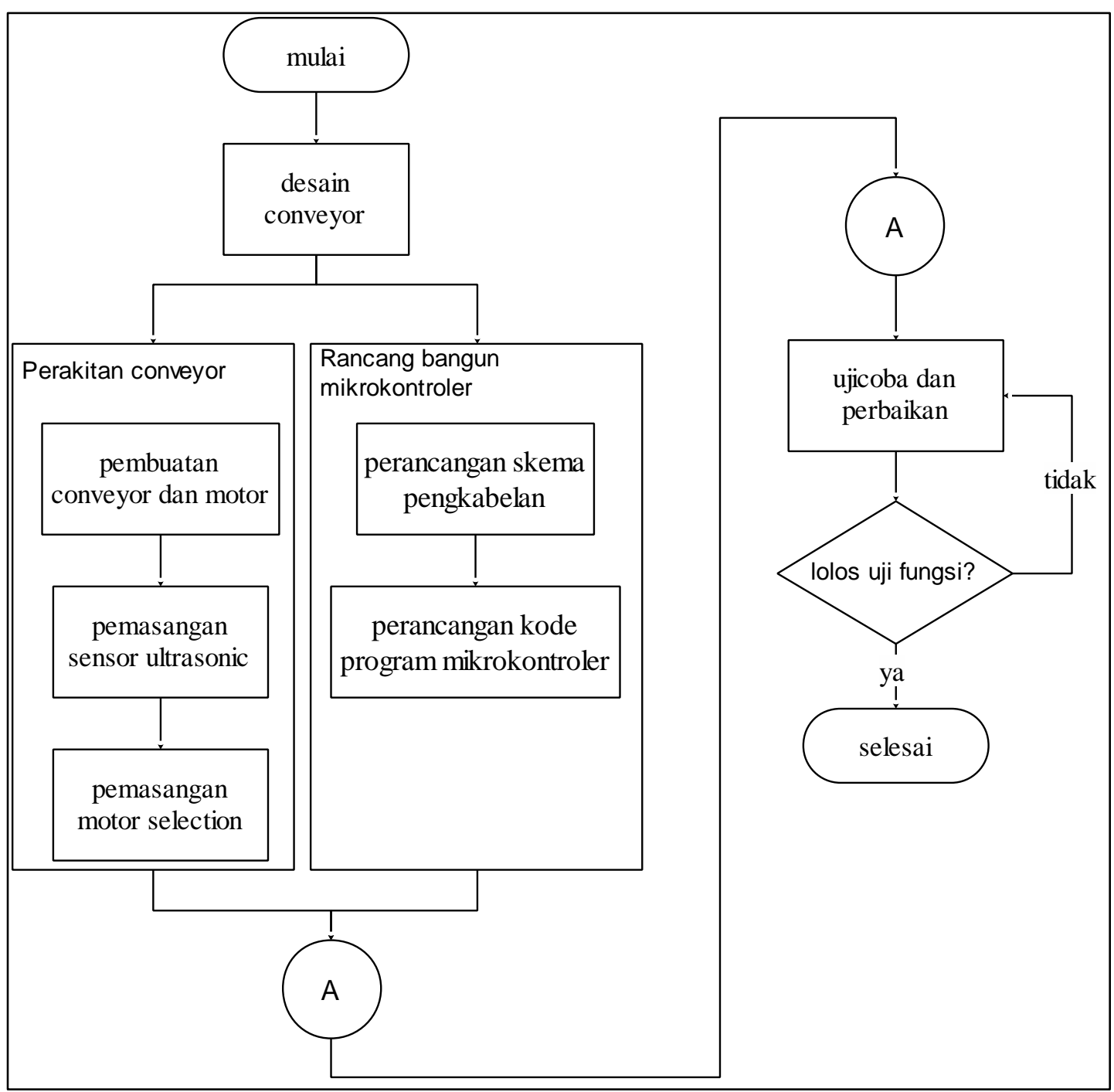

Gambar 3. Alur perancangan prototipe belt conveyor

\section{HASIL DAN PEMBAHASAN}

Penelitian ini dilakukan untuk melakukan rancang bangun belt conveyor dengan requirement specification seperti yang telah dijelaskan sebelumnya. Gambar 4 memperlihatkan rancang desain belt conveyor. Berdasarkan gambar sketsa rancang desain, dapat diketahui kebutuhan komponen untuk membuat belt conveyor yang sesuai dengan requirement specification. Tabel 2 memperlihatkan bill of material untuk rancang bangun belt conveyor. 


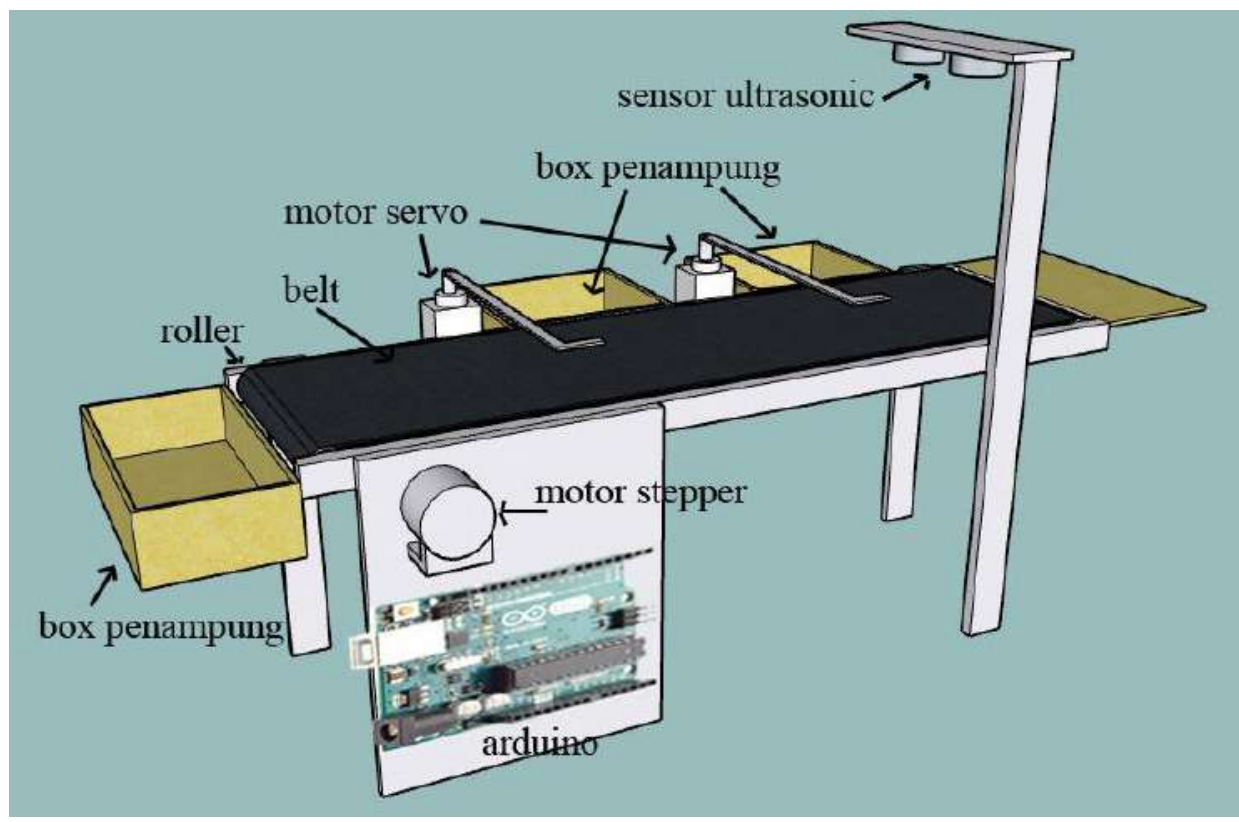

Gambar 4. Sketsa rancang desain belt conveyor

Tabel 2. Bill of materials untuk rancang bangun belt conveyor

\begin{tabular}{clcl}
\hline No & \multicolumn{1}{c}{ Material } & Jumlah & \multicolumn{1}{c}{ Fungsi } \\
\hline 1 & Arduino Uno R3 & 1 & Mikrokontroler \\
\hline 2 & Motor DC dan driver & 1 & Motor penggerak belt conveyor \\
\hline 3 & Motor servo SG-90 & 2 & Motor selector \\
\hline 4 & Sensor ultrasonic hc-sr04 & 1 & Sensor pengukur tinggi benda \\
\hline 5 & PVC Pralon 0.5 inch & $25 \mathrm{~cm}$ & Pulley penggerak belt conveyor \\
\hline 6 & Lakban hitam & 1 & Sabuk/ belt \\
\hline 7 & Kayu laban dan triplek & 1 & Body dan landasan belt conveyor \\
\hline
\end{tabular}

Untuk motor penggerak belt, digunakan motor DC berjenis stepper. Sementara untuk membuat belt (sabuk) menggunakan lakban hitam yang dimodif pada bagian permukaan lem. Sebagai pulley digunakan PVC Pralon yang dilem dengan gear tamiya. Gear tamiya ini yang nantinya akan berhubungan dengan as motor stepper. Sehingga ketika motor stepper bergerak, as motor ikut memutar gear dan pulley, pulley menggerakkan belt (sabuk).

Untuk perangkat pendeteksi tinggi benda, digunakan sensor ultrasonic HCSR04. Sensor ini memiliki ketelitian pembacaan hingga $0.5 \mathrm{~mm}$. Sedangkan untuk memilah benda ke keranjang 1 atau keranjang 2 digunakan motor servo yang ditambah lengan dari bahan es cream stick.

Berdasarkan gambar rancang desain dan penjelasan yang telah disampaikan di atas, Gambar 5 memperlihatkan belt conveyor yang telah dibangun. Rancang bangun conveyor tersebut mengikuti skema perancangan kabel seperti yang ditunjukkan pada Gambar 6. 


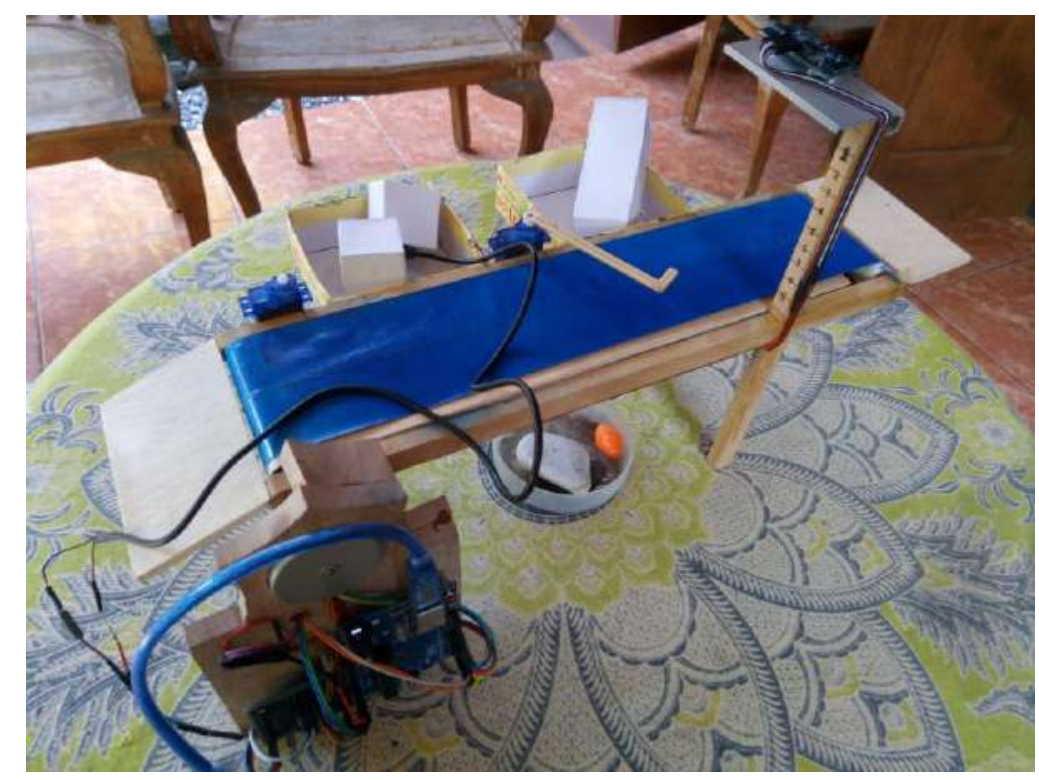

Gambar 5. Hasil rancang bangun belt conveyor

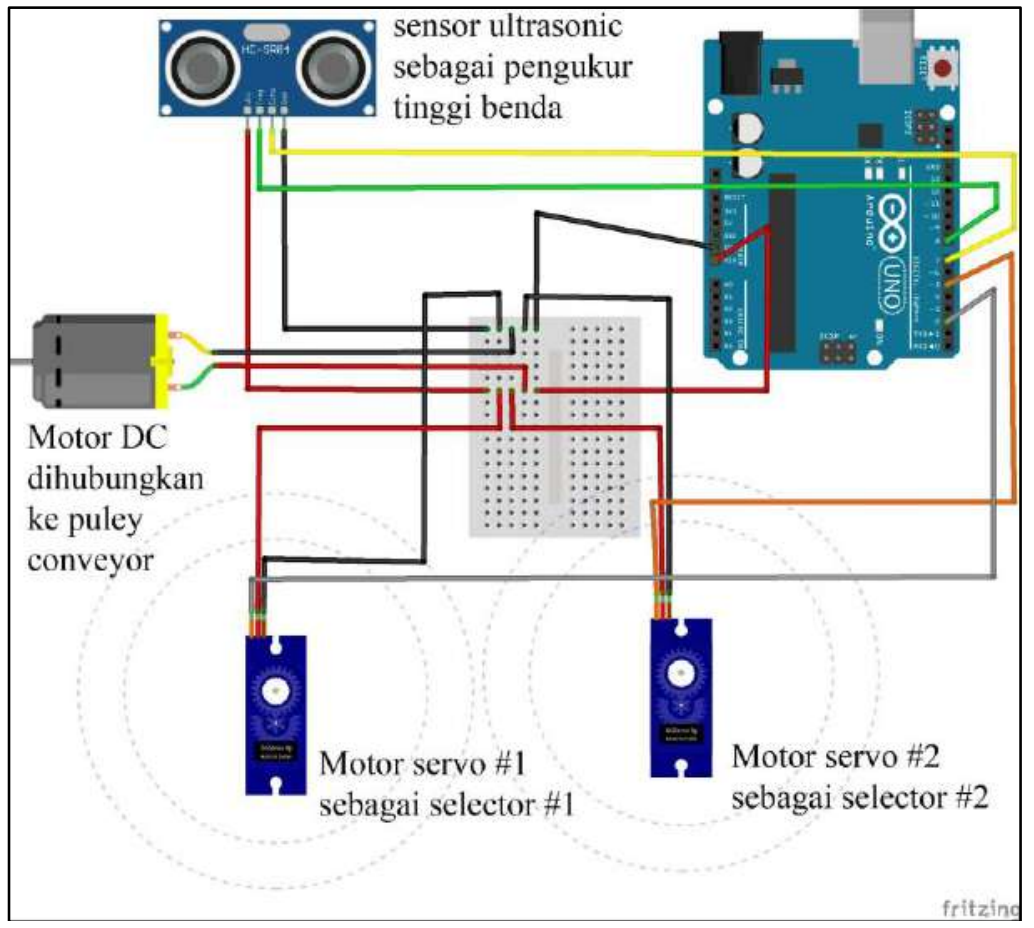

Gambar 6. Perancangan skema pengkabelan

Sedangkan Gambar 7 memperlihatkan rancang bangun kode program mikrokontroler sebagai pusat kendali belt conveyor. Sebagaimana terlihat, kode program yang dibangun menggunakan tiga buah library, yaitu library Stepper.h, Wire.h dan Servo.h. Library ini diperlukan untuk membantu komunikasi arduino dengan hardware lain, yaitu sensor ultrasonic, motor servo dan motor stepper.

Kode program baris $43 \mathrm{sd}$ baris 52 merupakan kendali gerak belt conveyor. Sementara kode program baris 65 sd baris 67 merupakan kendali sensor ultrasonic mengukur tinggi benda. Kemudian kode program baris 69 sd baris 83 merupakan kendali gerakan motor servo \#1 dan motor servo \#2 dalam pemilihan objek benda di conveyor. 


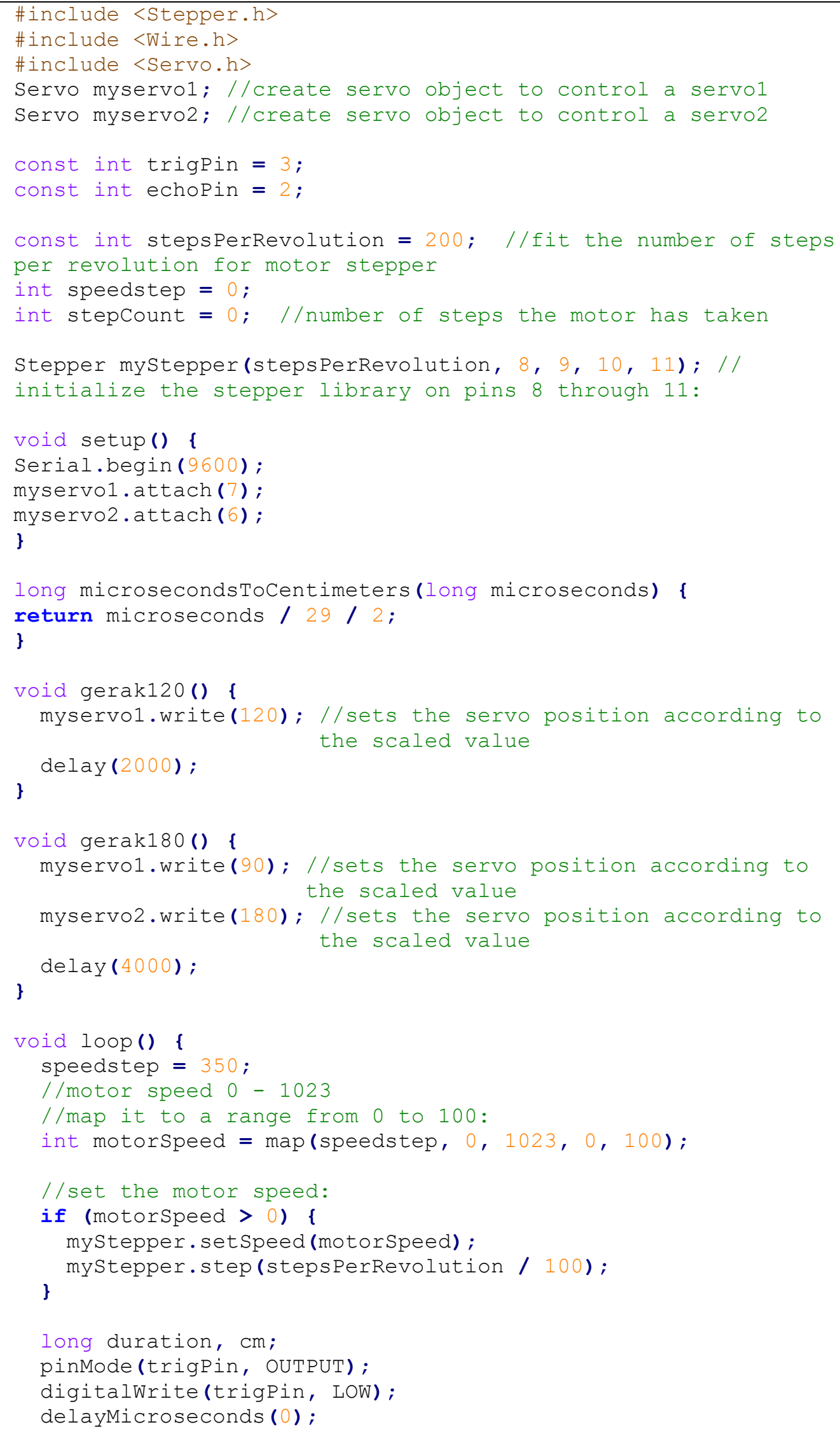




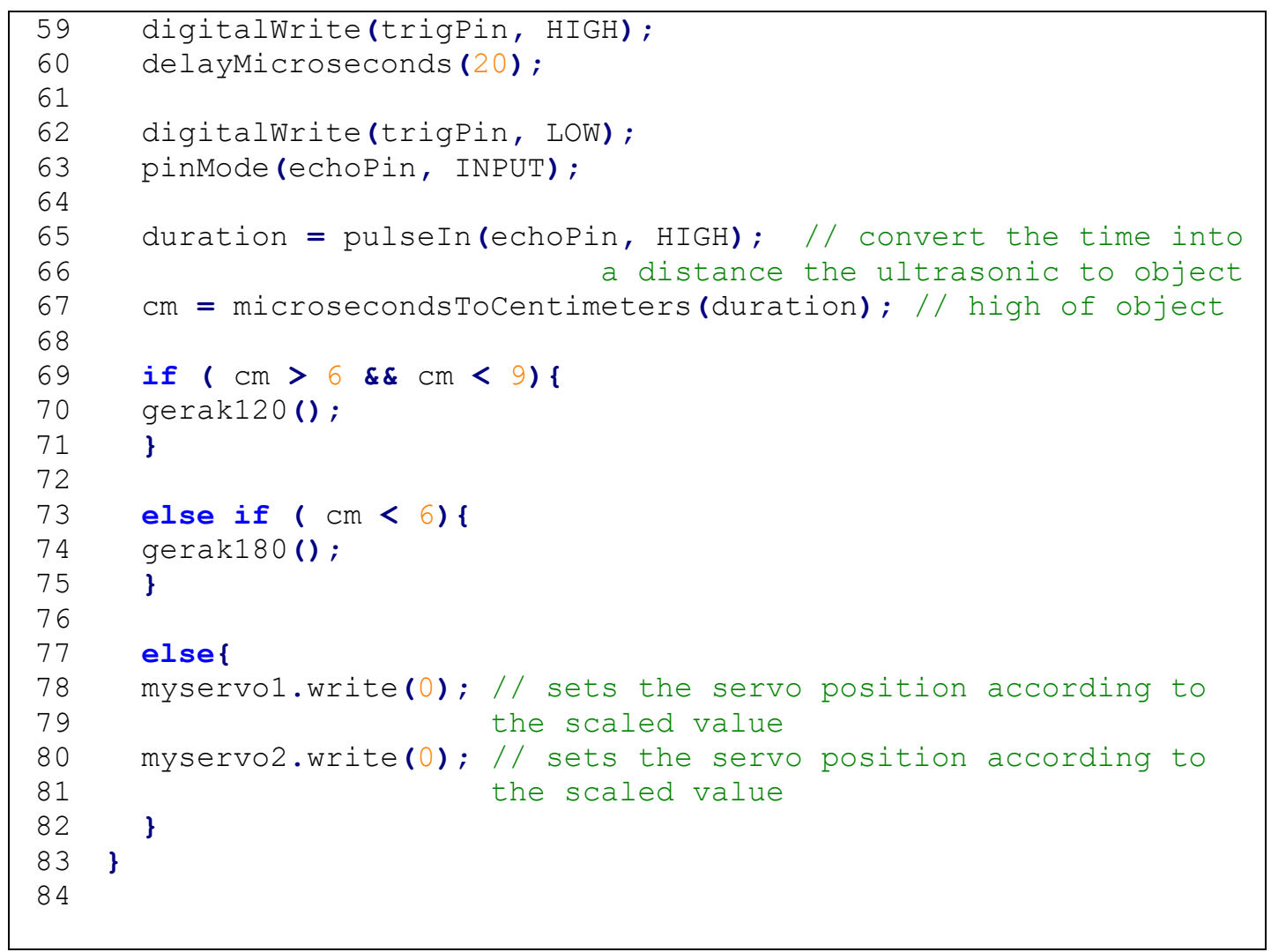

Gambar 7. Kode program mikrokontroler Arduino

Setelah kode program di-upload ke mikrokontroler Arduino, dilakukan ujicoba fungsional. Sebagai bahan ujicoba, disiapkan tiga buah objek dengan tinggi objek \#1 : $7 \mathrm{~cm}$, objek \#2 : $4 \mathrm{~cm}$ dan objek \#3 : 2,5 cm. Berat ketiga buah objek adalah 200 gram. Rekam foto ujicoba fungsional belt conveyor dapat dilihat dari Gambar 8 sd Gambar 10. Tabel 3 memperlihatkan rekap hasil ujicoba yang dilakukan.

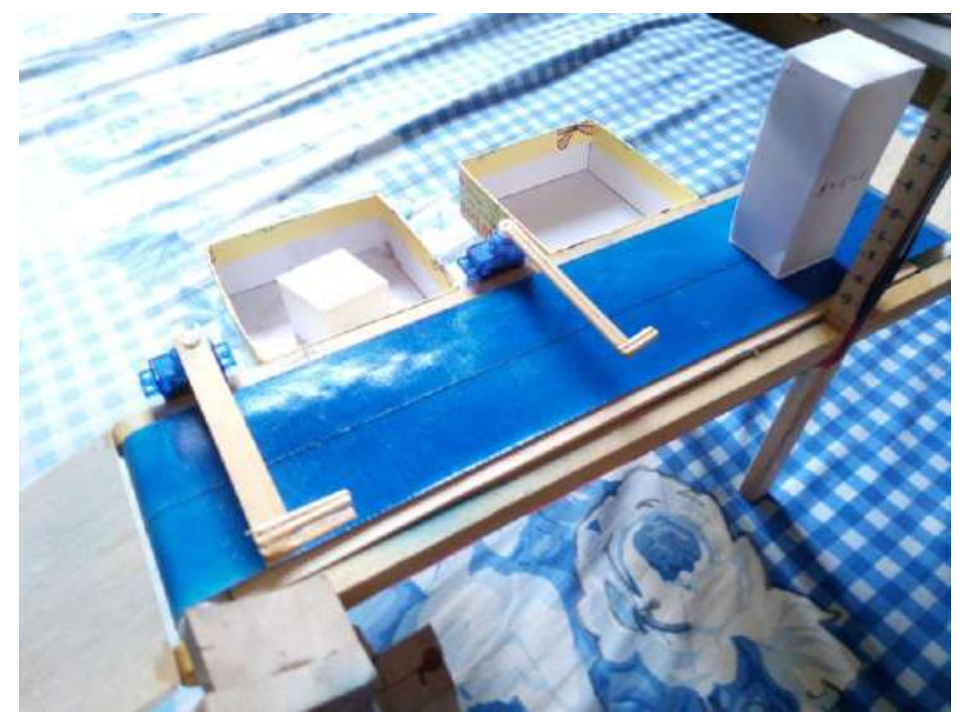

Gambar 8. Ujicoba pengukuran tinggi benda 


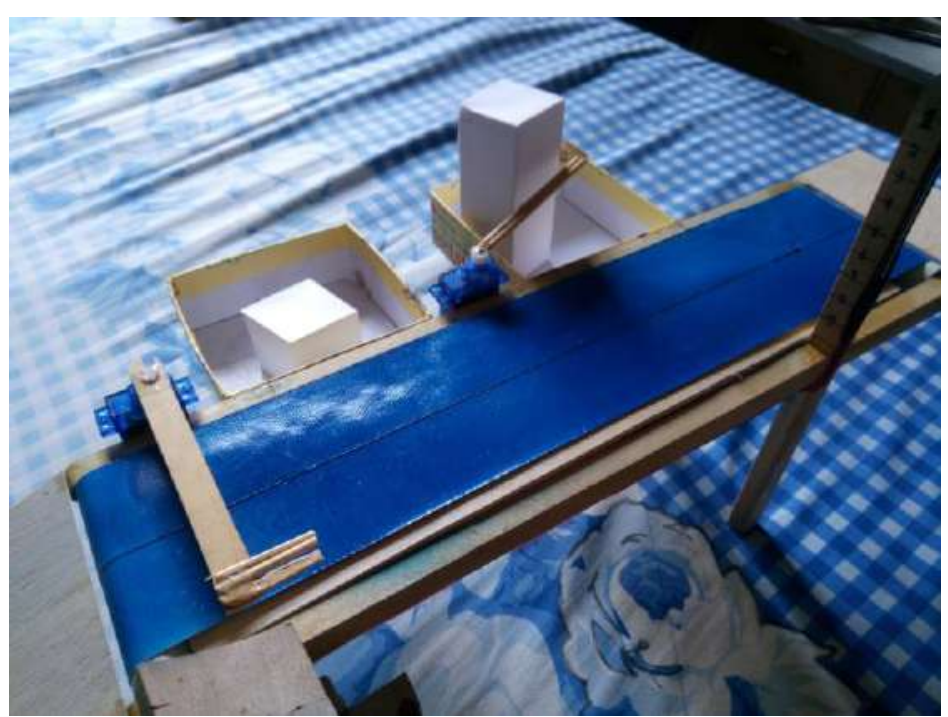

Gambar 9. Ketika tinggi benda $>6 \mathrm{~cm}$, terseleksi masuk keranjang \#1

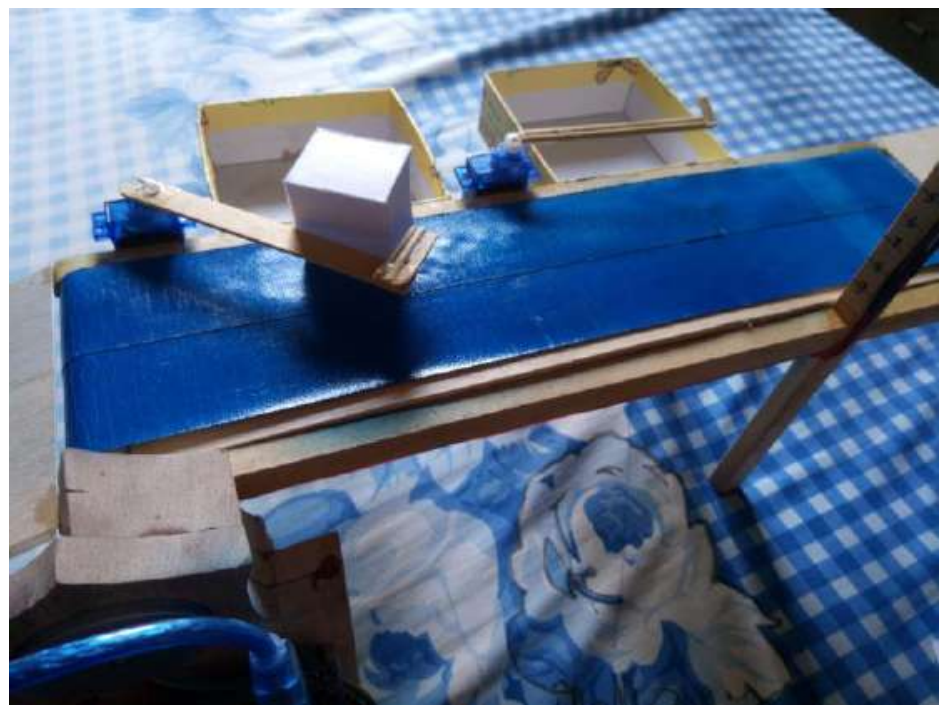

Gambar 10. Ketika tinggi benda $3 \mathrm{sd} 6 \mathrm{~cm}$, terseleksi masuk keranjang \#2

Tabel 3. Rekap hasil ujicoba fungsional

\begin{tabular}{cccc}
\hline No & Repetisi ke- & Tinggi benda & Hasil \\
\hline 1 & 1 & 7 & Objek terpilah masuk keranjang \#1 \\
\hline 2 & 2 & 7 & Objek terpilah masuk keranjang \#1 \\
\hline 3 & 3 & 7 & Objek terpilah masuk keranjang \#1 \\
\hline 4 & 1 & 4 & Objek terpilah masuk keranjang \#2 \\
\hline 5 & 2 & 4 & Objek terpilah masuk keranjang \#2 \\
\hline 6 & 3 & 4 & Objek terpilah masuk keranjang \#2 \\
\hline 7 & 1 & 2.5 & Objek terpilah masuk keranjang \#3 \\
\hline 8 & 2 & 2.5 & Objek terpilah masuk keranjang \#3 \\
\hline 9 & 3 & 2.5 & Objek terpilah masuk keranjang \#3 \\
\hline
\end{tabular}

\section{KESIMPULAN}

Sensor ultrasonic, motor servo, motor stepper dan Arduino dapat menjadi komponen untuk rancang bangun selection belt conveyor prototype. Hasil ujicoba 
fungsional menunjukkan prototipe conveyor berfungsi sesuai dengan requirement specification. Penelitian ini dapat dikembangkan lebih lanjut, seperti penambahan fungsi yang dapat melengkapi kebutuhan custom dari sebuah industri. Prototipe ini juga dapat diteliti lebih mendalam agar motor stepper mampu menggerakkan objek yang lebih besar dan lebih berat. Atau, prototipe ini dapat dikembangkan menjadi conveyor dalam skala 1:1.

\section{UCAPAN TERIMA KASIH}

Terima kasih disampaikan kepada Program Studi S1 Teknik Industri Universitas Setia Budi yang telah memberi dukungan finansial terhadap penelitian ini. Terima kasih juga disampaikan kepada Satria Lukmantoro dan Azizil Jabbar yang telah membantu pelaksanaan penelitian ini.

\section{DAFTAR PUSTAKA}

Bhirawa, W.T., 2018. Perancangan Meja Lipat Sederhana Dengan Menggunakan Google Sketch Up Software. J. Tek. Ind. 5. https://doi.org/10.35968/JTIN.V5I1.207

Mulyono, M., Hendaryati, R.H., Aziz, A., 2017. Rancang Bangun Belt Conveyor Untuk Penyaji Makanan, in: Prosiding SENTRA (Seminar Teknologi Dan Rekayasa). Fakultas Teknik - Universitas Muhammadiyah Malang, Malang. https://doi.org/10.22219/SENTRA.V0I3.1447

Nugraha, S.A., 2016. Rancang Bangun Sistem Konveyor Sabuk Pemilah Kopi Sangrai Dengan Pengendali Arduino Uno. Fakultas Teknik.

Nurhabiby, A.F., 2013. Perancangan Conveyor Mini Yang Dilengkapi Pemilah Benda Kerja Berdasarkan Dimensi Berbasis Mikrokontroler. Universitas Jember. 